\title{
Evaluation of fertilization with uncoated urea and 3,4-dimethylpyrazole phosphate (DMPP)-coated urea on nitrogen leaching and rose (Rosa spp.) yield
}

\author{
Alexandra García-Castro ${ }^{1}$, and Hermann Restrepo-Díaz ${ }^{*}$
}

The negative impact of $\mathrm{N}$ over-fertilization has acquired importance in rose (Rosa spp.) growers in Colombia. The nitrification inhibitor 3,4-dimethylpyrazole phosphate (DMPP) has been considered a valuable alternative to diminish the $\mathrm{N}$ losses by leaching and to enable more efficient $\mathrm{N}$ use efficiency in crops. The objective of the present work was to study the effect of DMPP on the mineral $\mathrm{N}\left(\mathrm{NH}_{4}{ }^{-}-\mathrm{N}\right.$ and $\left.\mathrm{NO}_{3}{ }^{-} \mathrm{N}\right)$ content in soil and water leaching, and physiological characteristics of rose plants. A greenhouse experiment was performed for $10 \mathrm{wk}$. Four-year-old 'Charlotte' rose cultivars grafted on 'Natal Briar' were grown in soil and fertirrigated daily with a complete nutrient solution containing $170 \mathrm{mg} \mathrm{N}$ $\mathrm{L}^{-1}$. Two $\mathrm{N}$ fertilizers (uncoated urea [UA], and urea $+1 \%$ DMPP [UDMPP]) were used. Results showed that UDMPP did not show any advantages on dry mass accumulation, $\mathrm{N}$ use efficiency, leaf area, number of marketable stems, SPAD readings, chlorophyll fluorescence, and leaf $\mathrm{N}$ concentration. Despite all these results, the addition of the inhibitor reduced mean $\mathrm{NO}_{3}{ }^{-}-\mathrm{N}$ concentrations in the percolated water by $65.81 \%$. These results suggest that UDMPP could be a valuable tool to reduce $\mathrm{NO}_{3}-\mathrm{N}$ leaching losses by retaining applied $\mathrm{N}$ in the ammoniacal form.

Key words: Chlorophyll fluorescence, leaf nitrogen concentration, nitrate leaching, nitrogen use efficiency.

\section{INTRODUCTION}

Colombia is the first rose (Rosa spp.) producing country in Latin America and the world second largest exporter of cut-flower (Flórez et al., 2006; Asocolflores, 2010).

Nitrogen $(\mathrm{N})$ is the main macronutrient that significantly influences on growth and productivity in all crops (Marschner, 1995; Maathuis, 2009). Nitrogen nutrition and its positive effects have been widely studied on morphological and physiological characteristics in rose plants. Studies have shown that $\mathrm{N}$ nutrition increases the number of flower-stems and leaves per flowerstem, the content of chlorophyll per leaf and/or leaf $\mathrm{N}$ concentration, and flower quality (Agbaria et al., 1996), enhances shoot development and bud break (Cabrera et al., 1995). Nitrogen application also improves $\mathrm{CO}_{2}$ assimilation and stomatal conductance (Hunt et al., 1985; Hak et al., 1993; Gonzalez-Real and Baille, 2000). Rose plant growers usually supply high amounts of $\mathrm{N}$ in order to obtain a vigorous growth and to guarantee a high yield (Cabrera, 2003). In ornamental plants, $\mathrm{N}$ over-fertilization may cause low $\mathrm{N}$ use efficiency (NUE) (Cabrera et al., 1993) and yield reductions (Barnett and Ormrod, 1985; Jull et al., 1994). Furthermore, this extensive use of $\mathrm{N}$ fertilizers may cause an increasing of the nitrate $\left(\mathrm{NO}_{3}\right.$

${ }^{1}$ Universidad Nacional de Colombia, Facultad de Agronomía, Edificio 500, Bogotá, Colombia.

*Corresponding author (hrestrepod@unal.edu.co).

Received: 25 November 2012.

Accepted: 28 March 2013.

doi:10.4067/S0718-58392013000200011.
-N) concentration in groundwater and/or drinking water (Villalobos et al., 2002).

The application of nitrification inhibitors $\left(\mathrm{NI}_{s}\right)$ or slow release fertilizers has been used to ameliorate $\mathrm{NO}_{3}$ -N leaching into groundwater and/or drinking water and to keep $\mathrm{NH}_{4}{ }^{+}$chemical species longer time in the soils (Paramasivam and Alva, 1997; Serna et al., 2000; Fernández-Escobar et al., 2004; Li et al., 2008). Currently, 3,4-dimethylpyrazole phosphate (DMPP) is one of the most known and used nitrification inhibitors in the $\mathrm{N}$ nutrition of crops during last decade (Zerulla et al., 2001). Several studies have demonstrated the positive effects of this molecule on the reduction of $\mathrm{N}$ losses $\left(\mathrm{NH}_{4}{ }^{+}-\mathrm{N}\right.$ and $\mathrm{NO}_{3}^{-}-\mathrm{N}$ ) in soil and leaching water (Serna et al., 2000; Li et al., 2008; Quiñones et al., 2009; Díez-López et al., 2008), increase of NUE (Villar and Guillaumes, 2010), and crop productivity (Irigoyen et al., 2006; Quiñones et al., 2009).

The negative impact of $\mathrm{N}$ over-fertilization has acquired importance in rose growers in Colombia (Flórez et al., 2006). Studies conducted by Henao and Flórez (2006) found that $\mathrm{NO}_{3}-\mathrm{N}$ concentration in the leaching water were above the limit allowed for drinking water (10 $\mathrm{mg} \mathrm{L}^{-1} \mathrm{NO}_{3}{ }^{-}-\mathrm{N}$ ) (US Department of Health, Education, and Welfare, 1962). Therefore, fertilization strategies have been studied to reduce the negative effects of $\mathrm{N}$ nutrition on the environment without affecting flower quality and yield (Flórez et al., 2006). In consequence, DMPP, which has been recently introduced in Colombia, is considered a valuable alternative to diminish $\mathrm{N}$ losses by leaching and to enable more efficient NUE in ornamental crops (Monomeros, 2008). Nevertheless, the 
available information on the effectiveness of this molecule in tropical soils is still limited; and the influence of the application of DMPP on plant rose physiology has not been investigated. Our hypothesis is that the application of DMPP-coated urea (UDMPP) will reduce nitrate leaching and will improve crop entire performances. The objectives of this work were to evaluate the effect of uncoated urea (UA) and DMPP-coated urea (UDMPP) on the either soil or leaching water nitrate content and physiological parameters such as growth, yield, flower quality, chlorophyll fluorescence, and NUE of rose 'Charlotte'.

\section{MATERIALS AND METHODS}

\section{Plant material and growth conditions}

This experiment was performed between April and June 2010 in a commercial greenhouse at "Centro de Bioctecnología Aplicada-Servicio Nacional de Aprendizaje (SENA)" in Mosquera (4² $42^{\prime} \mathrm{N}, 7^{\circ} 14^{\prime} \mathrm{W}$ ), Colombia, during $10 \mathrm{wk}$. Environmental conditions in the greenhouse were as follows: average temperature $20{ }^{\circ} \mathrm{C}$, mean global solar radiation $87.05 \mathrm{~W} \mathrm{~m}^{-2}, 35-100 \% \mathrm{RH}$ and a natural photoperiod 12:12 h. Four-year-old rose plants 'Charlotte' grafted on 'Natal Briar' were used. Individual plants were grown in 8 -L pots filled with a loam soil (30.3\% sand, $54.3 \%$ silt, and $14.7 \%$ clay), and the following chemical characteristics: total $\mathrm{N}: 0.5 \%(\sim$ 75 mg N kg-1), Ca: 24.4, K: 1.4, Mg: 8.4, Na: 6.8 meq $100 \mathrm{~g}^{-1}$; Cu: 4.6, Fe: 356.7, Mn 23:8; Zn: 51, B: 2, P: 140 $\mathrm{mg} \mathrm{kg}^{-1}, \mathrm{pH} 5.1$, and a cation exchange capacity (CEC) $38.1 \mathrm{cmol} \mathrm{kg}^{-1}$. Each plant container was placed at $0.5 \mathrm{~m}$ above 2-L plastic bucket in order to collect the percolate water. The harvest peak of roses was at $65 \mathrm{~d}$ after fertilizer treatments started (DAFTS). The plants received routine horticultural care suitable for commercial production during the experiment.

\section{Treatments}

Eight plants were used per treatment. Two $\mathrm{N}$ fertilizers treatments were established after shoot pinch. Each group of plants was treated with uncoated urea $(46 \% \mathrm{~N})$ or DMPP-coated urea, respectively. The rate of $\mathrm{N}$ applied was $170 \mathrm{mg} \mathrm{L}^{-1}$, since it is standard rate used by commercial rose growers in fertigation strategies in Colombia (Flórez et al., 2006). Additionally, the nutrient solution was completed by the addition of the following nutrients: 2.5 $\mathrm{mM} \mathrm{KCl}, 0.25 \mathrm{mM}$ calcium phosphate $\left[\mathrm{Ca}\left(\mathrm{H}_{2} \mathrm{PO}_{4}\right)_{2}\right], 1.0$ $\mathrm{mM}$ magnesium sulfate $\left(\mathrm{MgSO}_{4}\right), 12.5 \mu \mathrm{M}$ boric acid $\left(\mathrm{H}_{3} \mathrm{BO}_{3}\right), 1.0 \mu \mathrm{M}$ manganese sulfate $\left(\mathrm{MnSO}_{4}\right), 1.0 \mu \mathrm{M}$ zinc sulfate $\left(\mathrm{ZnSO}_{4}\right), 0.25 \mu \mathrm{M}$ copper sulfate $\left(\mathrm{CuSO}_{4}\right)$, $0.2 \mu \mathrm{M}$ ammonium molybdate $\left[\left(\mathrm{NH}_{4}\right)_{6} \mathrm{Mo}_{7} \mathrm{O}_{24}\right], 10 \mu \mathrm{M}$ Fe-ethylenediamine-di-o-hydroxyphenylacetic acid. In all cases, calcium hydroxide $\left[\mathrm{Ca}(\mathrm{OH})_{2}\right]$ was used to adjust the nutrient solution to $\mathrm{pH} 5.5$. Plants were irrigated daily with $850 \mathrm{~mL}$ of nutrient solution. The irrigation frequency was in five pulses applied each $2 \mathrm{~h}$, for 9 min beginning at 07:00 h. The experiment lasted $65 \mathrm{~d}$.

\section{Experimental analytical procedures}

Leaf chlorophyll fluorescence values were recorded at 44 and 65 DAFTS on a fully mature expanded leaf using a continuous excitation chlorophyll fluorescence analyzer (Handy PEA, Hansatech Instruments, King's Lynn, UK) in order to evaluate the maximum efficiency of photosystem II (Fv/Fm). Leaves were acclimated to the dark using lightweight leaf clips for at least 20 min before measurements were conducted. Leaf absorbance readings were also taken using a chlorophyll meter (SPAD-502; Minolta, Ramsey, New Jersey, USA) as a nondestructive tool for estimating leaf chlorophyll (Markwell et al., 1995). SPAD readings were also taken at 44 and 65 DAFTS. According to Cabrera (2006), two fully expanded leaves from superior-portion of marketable stem were collected to estimate leaf area and leaf $\mathrm{N}$ concentration. Leaf area was determined using a leaf area meter (Licor 3100C, LICOR, Lincoln, Nebraska, USA). Then, leaves were dried at $80{ }^{\circ} \mathrm{C}$ for $72 \mathrm{~h}$ and dry mass (DM) of the same leaves were measured gravimetrically. Subsequently, dry leaves were used to determine leaf $\mathrm{N}$ concentrations by the Kjeldahl procedure. Nitrogen use efficiency (NUE) and $\mathrm{N}$ usage index were estimated using the equation described by Good et al. (2004) and Melgar et al. (2010), respectively. Additionally, leaf $\mathrm{N}$ content per unit area $\left(\mathrm{N}_{\mathrm{a}}\right.$ $=\mathrm{g} \mathrm{N} \mathrm{m}^{-2}$ ) was also determined by dividing leaf $\mathrm{N}$ content of one leaf by its leaf area. Measurements of total number of stem-flowers, stem length, stem diameter, and flower bud size were also recorded.

Leachates from containers were collected in a 200 $\mathrm{mL}$ pot each $10 \mathrm{~d}$. Then, the sample was filtered and stored at $4{ }^{\circ} \mathrm{C}$ until nitrate or ammonium analysis. Nitrate and ammonium content in the leachate was determined by the technique described by Taras (1967). Ammonium and nitrate readings were performed with a spectrophotometer (Lambda 25 UV/Vis, PerkinElmer, Wellesley, Massachusetts, USA). The electrical conductivity $\left(\mathrm{EC}, \mu \mathrm{S} \mathrm{cm} \mathrm{cm}^{-1}\right.$ ) of each leachate fraction was measured using a portable waterproof $\mathrm{pH} / \mathrm{CON} 10$ Meter (Oakton Instruments, Vernon Hills, Illinois, USA). The ionic strength $(\mathrm{I}, \mathrm{mM})$ of the leachate was estimated using $\mathrm{EC}$ values according to the relationship of $\mathrm{I}=0.013 \mathrm{EC}$. Ionic strength of the leachate is an indirect measure of presence of ions in the soil solution (Alva et al., 1991; Paramasivam and Alva, 1997).

Soil samples were collected from upper $20 \mathrm{~cm}$ of each pot at 0 and 65 DAFTS for the determination of ammonium and nitrate. Ammonium and nitrate determinations were performed by the $\mathrm{KCl}$ extraction-distillation method described by Mulvaney (1996).

\section{Statistical analysis}

Data were subjected to ANOVA using a completely 
randomized design. All percentage values were transformed using the arcsine transformation before analysis. Where a significant $F$-test was observed, mean separation among treatments was obtained by Tukey's test. Data were analyzed using Statistix (version 8.0; Analytical Software, Tallahassee, Florida, USA). Graphs were performed using software Sigmaplot (v. 10.0; Systat Software, San Jose, California, USA).

\section{RESULTS AND DISCUSSION}

\section{Growth characteristics and yield components}

Nitrogen fertilizer treatments did not show any differences on growth characteristics such as flower stem length and diameter, and flower bud size and diameter during the experiment (Table 1). Likewise, neither uncoated urea nor DMPP-coated urea had an effect on dry mass accumulation (dry mass of leaves, flower stem, and flower bud), and growth characteristics (Table 2).

Similar trends were found on leaf $\mathrm{N}$ concentration, NUE, $\mathrm{N}$ usage index, leaf $\mathrm{N}$ content per unit area $\left(\mathrm{N}_{\mathrm{a}}=\mathrm{g}\right.$ $\mathrm{N} \mathrm{m}^{-2}$ ) and yield (number of flower stems per plant) due to $\mathrm{N}$ treatments (Table 3). In all cases, leaf $\mathrm{N}$ concentration was between the rank 3-4\% considered as the optimum leaf concentration for rose plants (Cabrera, 2000). Also, Cabrera (2000) and Cabrera (2006) mentioned that leaf $\mathrm{N}$ value above $3 \%$ per se is not a not a dependable indicator of rose productivity, since this value has been obtained without consider factors such as quantitative parameters of yield (biomass or number of flowers harvested).

SPAD readings and the efficiency of photosystem

Table 1. Flower stem length, flower stem diameter, flower bud length and size of 'Charlotte' rose fertilized with urea alone (UA) and urea+1\% 3,4-dimethylpyrazole phosphate (UDMPP). Values are means of eight replicates.

\begin{tabular}{lcccc}
\hline & $\begin{array}{c}\text { Flower } \\
\text { stem } \\
\text { length }\end{array}$ & $\begin{array}{c}\text { Flower } \\
\text { stem } \\
\text { diameter }\end{array}$ & $\begin{array}{c}\text { Flower } \\
\text { bud } \\
\text { size }\end{array}$ & $\begin{array}{c}\text { Flower } \\
\text { bud } \\
\text { diameter }\end{array}$ \\
\hline Fertilizer & $\mathrm{cm}$ & & $\mathrm{mm}$ & \\
UDMPP & 72.26 & 0.76 & 42.25 & 27.28 \\
UA & 64.93 & 0.66 & 45.85 & 29.51 \\
Significance & $\mathrm{NS}$ & $\mathrm{NS}$ & $\mathrm{NS}$ & $\mathrm{NS}$ \\
CV,\% & 22.81 & 18.7 & 18.99 & 23.45 \\
\hline
\end{tabular}

$\mathrm{CV}$ : Coefficient of variation; NS: non-significant.

Table 2. Dry mass of flower-stem leaves, dry mass of flower-stem, dry mass of flower-bud, total dry mass, and leaf area of 'Charlotte' rose fertilized with urea alone (UA) and urea+1\% nitrification inhibitor 3,4-dimethylpyrazole phosphate (UDMPP). Values are means of eight replicates.

\begin{tabular}{lccccc}
\hline & $\begin{array}{c}\text { Dry } \\
\text { mass } \\
\text { leaves }\end{array}$ & $\begin{array}{c}\text { Dry mass } \\
\text { flower } \\
\text { stem }\end{array}$ & $\begin{array}{c}\text { Dry mass } \\
\text { flower } \\
\text { bud }\end{array}$ & $\begin{array}{c}\text { Total } \\
\text { dry } \\
\text { mass }\end{array}$ & $\begin{array}{c}\text { Leaf } \\
\text { area }\end{array}$ \\
\cline { 2 - 4 } Fertilizer & & & & & $\mathrm{cm}^{2}$ \\
UDMPP & 2.60 & 3.00 & 2.11 & 7.70 & 161.74 \\
UA & 2.12 & 3.60 & 2.02 & 7.74 & 141.90 \\
Significance & $\mathrm{NS}$ & $\mathrm{NS}$ & $\mathrm{NS}$ & $\mathrm{NS}$ & $\mathrm{NS}$ \\
CV, $\%$ & 27.01 & 21.56 & 15.66 & 16.46 & 13.82 \\
\hline
\end{tabular}

CV: Coefficient of variation; NS: non-significant.
Table 3. Leaf $\mathrm{N}$ concentration, leaf $\mathrm{N}$ content per unit area ( $\mathrm{Na}$ basis), $\mathrm{N}$ use efficiency (NUE), $\mathrm{N}$ usage index and flower stem yield of 'Charlotte' rose fertilized with urea alone (UA) and urea+1\% nitrification inhibitor 3,4-dimethylpyrazole phosphate (UDMPP). Values are means of eight replicates.

\begin{tabular}{lccccc}
\hline & $\begin{array}{c}\text { Leaf N } \\
\text { content }\end{array}$ & $\begin{array}{c}\mathrm{Na} \\
\text { basis }^{\mathrm{a}}\end{array}$ & NUE & $\begin{array}{c}\text { N usage } \\
\text { index }\end{array}$ & Yield \\
\hline Fertilizer & $\%$ & $\mathrm{~g} \cdot \mathrm{m}^{2}$ & $\%$ & $\%$ & $\begin{array}{c}\text { Flower stems/ } \\
\text { plant }\end{array}$ \\
UDMPP & 3.49 & 5.58 & 28.83 & 75.00 & 4.87 \\
UA & 3.38 & 5.18 & 29.59 & 62.41 & 5.37 \\
Significance & $\mathrm{NS}$ & $\mathrm{NS}$ & $\mathrm{NS}$ & $\mathrm{NS}$ & $\mathrm{NS}$ \\
CV, $\%$ & 7.21 & 29.23 & 7.09 & 28.31 & 46.02 \\
\hline
\end{tabular}

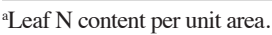

CV: Coefficient of variation; NS: non-significant.

II (PSII) (expressed as Fv/Fm) were not affected by $\mathrm{N}$ fertilizers at 44 and 65 DAFTS (Table 4). On the other hand, differences were not observed on the number of marketable stems $(40-75 \mathrm{~cm})$ at the end of the experiment (Figure 1). Works conducted by Díez-López et al. (2008) and Rodrigues et al. (2010) also observed that neither uncoated urea nor DMPP-coated urea caused differences on dry mass yield, NUE, SPAD readings and/or tissue $\mathrm{N}$ concentration in maize (Zea mays L.) and tall cabbage (Brassica olearacea L.), respectively. Although DMPPcoated urea did not show differences on physiological parameters such as DM, yield, NUE, leaf chlorophyll readings and number marketable stems compared uncoated-urea. A more plausible explanation to the lack of response in rose plants to the use of DMPP could be the fact that plants can easily take up $\mathrm{NO}_{3}{ }^{-}$and $\mathrm{NH}_{4}{ }^{+}$, and may advantage from the presence of both forms in soil solution (Cao and Tibbitts, 1993). DMPP-coated urea has $7.5 \%$ $\mathrm{NO}_{3}-\mathrm{N}, 18.5 \% \mathrm{NH}_{4}-\mathrm{N}$ and $0.8 \%$ DMPP (Rodrigues et al., 2010). In addition, urea is rapidly hydrolyzed to $\mathrm{NH}_{4}{ }^{+}$ which is subsequently transformed in $\mathrm{NO}_{3}{ }^{-}$(Paramasivam and Alva, 1997; Rodrigues, 2004). In consequence, in both DMPP-coated urea and uncoated- Urea pots, $\mathrm{NH}_{4}{ }^{+}$ and/or $\mathrm{NO}_{3}{ }^{-}$could be available for plant uptake.

\section{Ionic strength}

Significant differences were found in I of leachate at 30, 40 , and 50 DAFTS among fertilizer treatments, being I lower in the collected from soils treated with DMPP (Figure 2). This observation agrees with the finding of

Table 4. SPAD readings and leaf chlorophyll fluorescence $(\mathrm{Fv} / \mathrm{Fm})$ at 44 and $65 \mathrm{~d}$ after fertilizer treatments started (DAFTS) of 'Charlotte' rose fertilized with urea alone (UA) and urea+1\% nitrification inhibitor 3.4-dimethylpyrazole phosphate (UDMPP). Values are means of eight replicates.

\begin{tabular}{lccccc}
\hline & \multicolumn{2}{c}{44 DAFTS } & & \multicolumn{2}{c}{65 DAFTS } \\
\cline { 2 - 3 } \cline { 6 - 6 } & SPAD & Fv/Fm & & SPAD & Fv/Fm \\
\hline Fertilizer & & & & & \\
UDMPP & 52.95 & 0.83 & & 52.92 & 0.84 \\
UA & 51.80 & 0.83 & & 54.09 & 0.83 \\
Significance & NS & NS & & NS & NS \\
CV, $\%$ & 12.17 & 1.71 & & 5.87 & 1.69 \\
\hline
\end{tabular}

$\mathrm{CV}$ : Coefficient of variation; NS: non-significant. 

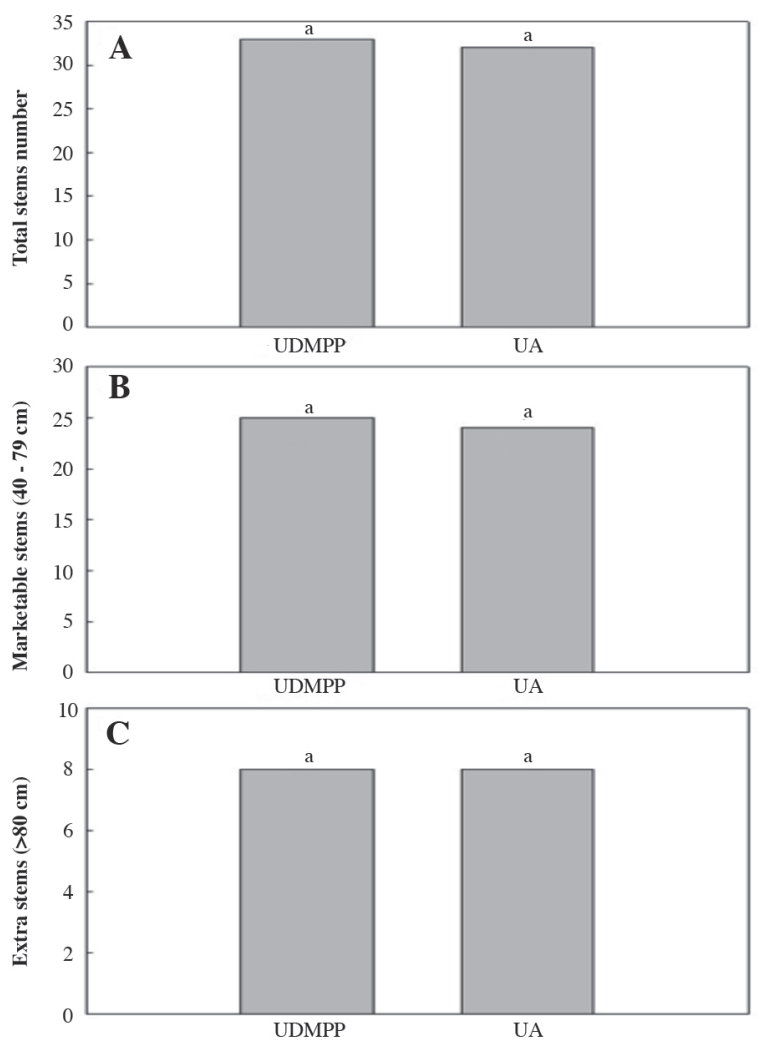

Figure 1. Effect of the application of two $\mathrm{N}$ fertilizers (urea alone [UA] and urea+1\% 3,4-dimethylpyrazole phosphate [UDMPP]) on flower stem quality per container of 'Charlotte' rose. Values are means of eight replicates and bars show standard error. Different letters are significantly different according to Tukey's test $(\mathrm{P} \leq \mathbf{0 . 0 5})$.

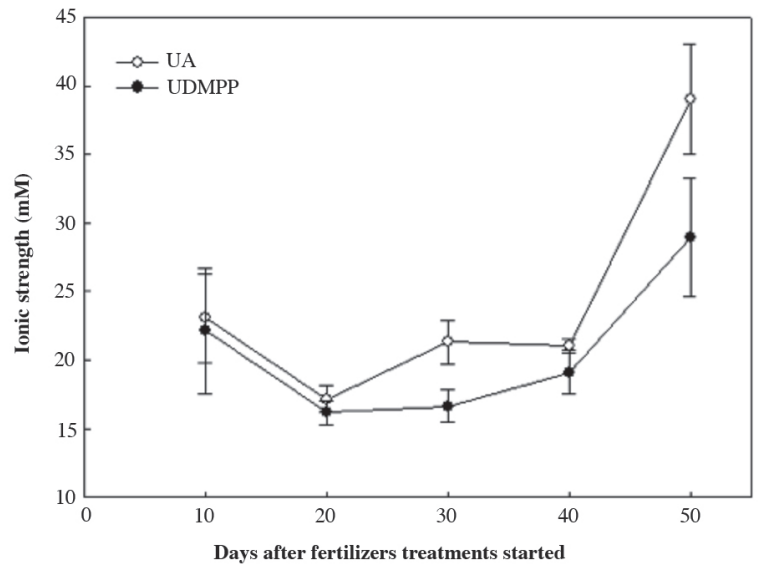

Figure 2. Ionic strength from loam soil treated with two $\mathbf{N}$ fertilizers (urea alone [UA] and urea+1\% 3,4-dimethylpyrazole phosphate [UDMPP]). Values are means of eight replicates and bars show standard error.

Paramasivam and Alva (1997) where the leachates from soils were treated with Osmocote (a selected urea-based controlled-release fertilizer) showed a lower I than the ones treated with urea. A more plausible explanation to I differences between untreated and treated urea could be the fact that the hydrolysis of urea (without coating) and subsequent transformations are fairly rapid as compared to those reactions for the other urea coated with DMPP (Paramasivam and Alva, 1997).

\section{$\mathrm{NH}_{4}{ }^{+}-\mathrm{N}$ and $\mathrm{NO}_{3}{ }^{-}-\mathrm{N}$ losses by leaching}

Ammonium concentration in the leaching water of the two $\mathrm{N}$ fertilizers studied is shown in Figure 3A. At 30 DAFTS, $\mathrm{NH}_{4}{ }^{+}-\mathrm{N}$ concentrations in UDMPP treated soil showed significant differences and reached highest values of $35.71 \mathrm{mg} \mathrm{NH}_{4}{ }^{+}-\mathrm{N} \mathrm{pot}^{-1}$ compared to values observed in UA pots $\left(11.18 \mathrm{mg} \mathrm{NH}_{4}{ }^{+}-\mathrm{N}^{-1}\right.$ pot $\left.^{-1}\right)$. Then, a gradual decrease was observed in both treatments until the end of the experiment. Studies conducted by Fernández-Escobar et al. (2004) also reported similar trends on the patterns of ammonium leaching in olive plants treated with urea, ammonium sulfate, a S-coated urea (Greenmaster Super, Scott OM España SA, Tarragona, Spain), and a nitrification inhibitor (Basammon Stabil, BASF, Ludwigshafen, Germany).

Significant differences were also observed on nitrate concentration in the leachates throughout the duration of the experiment among fertilizer treatments (Figure 3B). UDMPP had an inhibitory effect on nitrate content in the
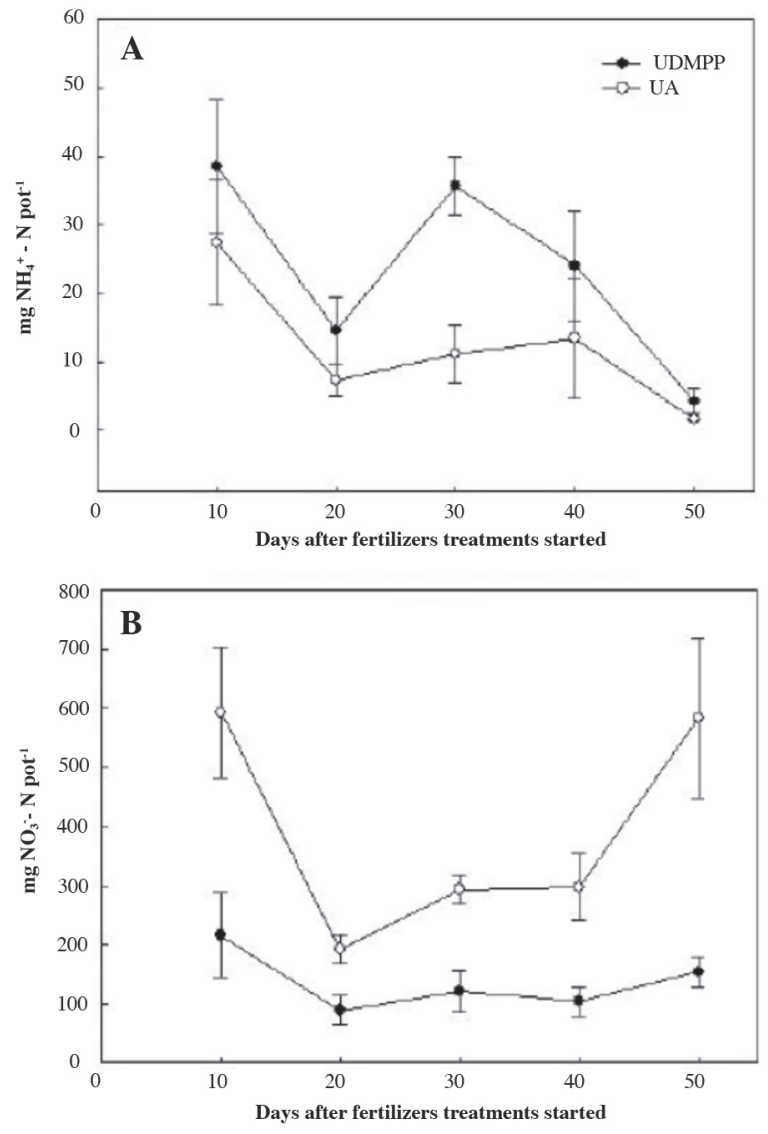

Figure 3. Amounts of $\mathrm{NH}_{4}{ }^{+}-\mathrm{N}$ and $\mathrm{NO}_{3}{ }^{-} \mathrm{N}$ leached into drainage water from soil treated with two $\mathrm{N}$ fertilizers (urea alone [UA] and urea+1\% 3,4-dimethylpyrazole phosphate [UDMPP]). Values are means of eight replicates and bars show standard error. 
leachate. Nitrate losses by leaching were lower in UDMPP treatments than UA treatments. Maximum nitrate losses were observed at 10 and 50 DAFTS in UA treatments, 593.12 and $583.15 \mathrm{mg} \mathrm{NO}_{3}^{-}-\mathrm{N}_{\text {pot }}{ }^{-1}$, respectively. UDMPP reduced the mean $\mathrm{NO}_{3}{ }^{-}-\mathrm{N}$ concentrations in the leachate by $65.18 \%$ in a 3 -mo experiment. Also, the highest nitrate losses observed at the end of the experiment in rose plants treated with UA can be due to a rapid urea hydrolysis and nitrification (Paramasivam and Alva, 1997). Li et al. (2008), in a 3-mo experiment in rice, also found that DMPP had an inhibitory effect on nitrate content in the leachate since the average concentrations of $\mathrm{NO}_{3}{ }^{-}-\mathrm{N}$ in the leachate from UDMP treatments were $44.49 \%$ lower than from UA treatments.

On the other hand, cumulative ammonium and nitrate losses by leaching are shown in Figure 4. Leachates collected from fertilized pots contained elevated $\mathrm{NO}_{3}{ }^{-}-\mathrm{N}$ levels and very low $\mathrm{NH}_{4}{ }^{+}-\mathrm{N}$ contents. The total amount of $\mathrm{NO}_{3}^{-}-\mathrm{N}$ leached from the UDMPP treatment was much lower than that found in the UA treatment. Nitrate losses by leaching were 2726.84 and $7831.71 \mathrm{mg} \mathrm{NO}_{3}^{-}-\mathrm{N}$ for UDMPP and UA treatments, respectively. In contrast, the amount of $\mathrm{NH}_{4}{ }^{+}-\mathrm{N}$ in drainage water was higher in the treatment with UDMPP (469.19 $\left.\mathrm{mg} \mathrm{NH}_{4}{ }^{+}-\mathrm{N}\right)$ than with UA (236.78 $\mathrm{mg} \mathrm{NH}_{4}{ }^{+}-\mathrm{N}$ ). Serna et al. (2000) working on a soil cultivated with Citrus, also reported that DMPP was able to reduce accumulative total $\mathrm{NO}_{3}-\mathrm{N}$ losses and to increase $\mathrm{NH}_{4}{ }^{+}-\mathrm{N}$ concentrations in the leachate.
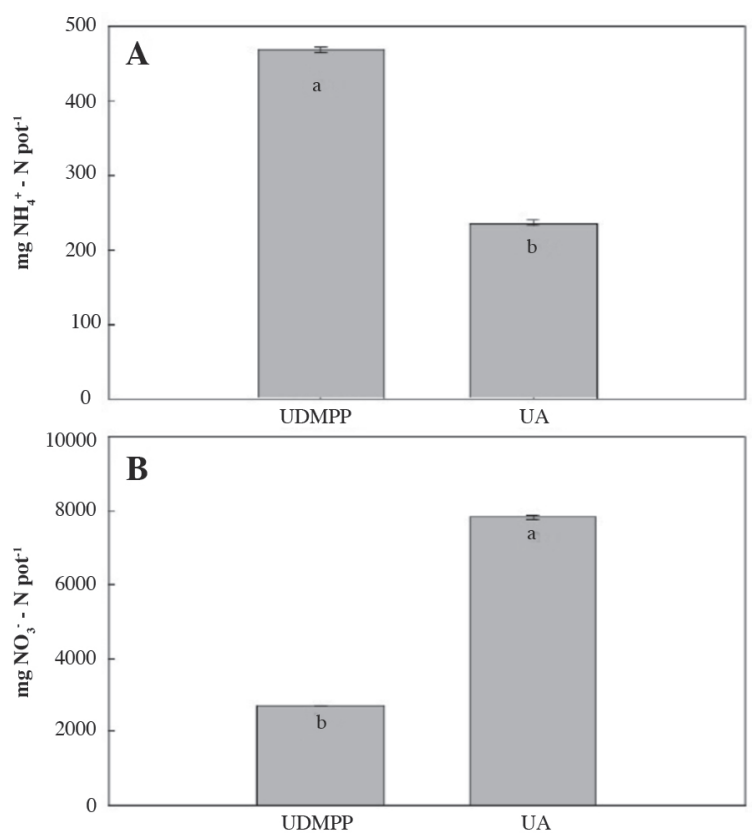

Figure 4. Total cumulative $\mathrm{NH}_{4}{ }^{+}-\mathrm{N}$ and $\mathrm{NO}_{3}-\mathrm{N}$ loss in drainage water from two $\mathrm{N}$ fertilizers (urea alone [UA] and urea+1\% 3,4-dimethylpyrazole phosphate [UDMPP]). Values are means of eight replicates and bars show standard error. Different letters are significantly different according to Tukey's test $(P \leq 0.05)$.

\section{Ammonium and nitrate content in soil after $\mathbf{N}$} fertilization

Differences were not observed among fertilizer treatments on ammonium and nitrate content in soil at beginning of the experiment (0 DAFTS). The application of urea increased significantly ammonium and nitrate concentrations in soil at end of experiment (65 DAFTS); however, the application of DMPP reduced soil nitrate concentration by $28.8 \%$, compared UA treatments (Table 5). Similar observations were obtained by Serna et al. (2000) and Li et al. (2008), also observed that the application of DMPP resulted in a significant diminish in soil nitrate concentration in comparison with plants fertilized with ammonium sulfate and urea alone.

Table 5. $\mathrm{NH}_{4}{ }^{+}-\mathrm{N}$ and $\mathrm{NO}_{3}^{-}-\mathrm{N}$ concentrations in soils at 0 and $65 \mathrm{~d}$ after fertilizer treatments started (DAFTS). Values are means of eight replicates.

\begin{tabular}{|c|c|c|c|c|}
\hline & \multicolumn{2}{|c|}{0 DAFTS } & \multicolumn{2}{|c|}{65 DAFTS } \\
\hline & $\mathrm{NH}_{4}{ }^{+}-\mathrm{N}$ & $\mathrm{NO}_{3}-\mathrm{N}$ & $\mathrm{NH}_{4}{ }^{+}-\mathrm{N}$ & $\mathrm{NO}_{3}-\mathrm{N}$ \\
\hline & 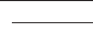 & $\mathrm{n}$ & & - \\
\hline \multicolumn{5}{|l|}{ Fertilizer } \\
\hline UDMPP & 778.68 & 343.29 & $1179.3 b$ & $1192.3 b$ \\
\hline UA & 661.34 & 962.38 & $1641.9 \mathrm{a}$ & $1674.6 \mathrm{a}$ \\
\hline Significance & NS & NS & $* *$ & $* *$ \\
\hline $\mathrm{CV}, \%$ & 19.55 & 68.78 & 11.71 & 20.48 \\
\hline
\end{tabular}

Within a column and factor followed by different letters are significantly different according to Tukey's test $(\mathrm{P} \leq 0.05)$.

UDMPP: Urea+1\% 3,4-dimethylpyrazole phosphate; UA: urea; CV: coefficient of variation; NS: non-significant; ${ }^{* *}$ : significant at $\mathrm{P} \leq 0.01$.

\section{CONCLUSIONS}

In spite of the fact the use of DMPP-coated urea did not showed any physiological advantage compared to uncoated urea, possibly because of both $\mathrm{NH}_{4}{ }^{+}$and $\mathrm{NO}_{3}{ }^{-}$ forms can be up taken by the plant. However; these results suggest that the application of DMPP could be a valuable tool to reduce $\mathrm{NO}_{3}^{-}-\mathrm{N}$ leaching losses by retaining applied $\mathrm{N}$ in the ammoniacal form in order to ameliorate the negative impact of nitrogen fertilization on the agrosystem of rose crops in Colombia.

\section{ACKNOWLEDGEMENTS}

This work was supported by División de Investigación de la Universidad Nacional de Colombia, Campus Bogotá. Also, authors acknowledge Centro de Biotecnología del Servicio Nacional de Aprendizaje (SENA) for technical facilities during the development of this research.

\section{LITERATURE CITED}

Agbaria, H., B. Heuer, and N. Zieslin. 1996. Shoot-root interaction effects on nitrate reductase and glutamine synthetase activities in rose (Rosa $\times$ hybrida cvs. Ilseta and Mercedes) graftlings. Journal of Plant Physiology 149:559-563. 
Alva, A.K., M.E. Sumner, and W.P. Miller. 1991. Relationship between ionic strength and electrical conductivity for soil solutions. Soil Science 152:239-242.

Asocolflores. 2010. Colombian floriculture, 2009 Statistics. Association of Colombian Flower Exporters. Available at http:// www.asocolflores.org (accessed November 2012).

Barnett, C.E., and D.P. Ormrod. 1985. Responses of Tilia cordata and Acer platanoides in pots to nitrogen levels. HortScience 20:283-285

Cabrera, R. 2000. Evaluating yield and quality of roses with respect to nitrogen fertilization and leaf tissue nitrogen status. Acta Horticulturae 511:133-140.

Cabrera, R. 2003. Nitrogen balance for two container-grown woody ornamental plants. Scientia Horticulturae 97:297-308.

Cabrera, R. 2006. Consideraciones sobre nutrición mineral y fertilización en rosas. p. 145-1622. In V. Flórez et al. (eds.) Avances sobre fertirriego sobre la floricultura colombiana. Universidad Nacional de Colombia, Unibiblos, Bogotá, Colombia.

Cabrera, R., R. Evans, and J. Paul. 1993. Leaching losses of N from container-grown roses. Scientia Horticulturae 53:333-345.

Cabrera, R., R. Evans, and J. Paul. 1995. Cyclic nitrogen uptake by greenhouse roses. Scientia Horticulturae 63:57-66.

Cao, W., and T.W. Tibbitts. 1993. Study of various $\mathrm{NH}_{4}{ }^{+} / \mathrm{NO}_{3}{ }^{-}$ mixtures for enhancing growth of potatoes. Journal of Plant Nutrition 16:1691-1704.

Díez-López, J., P. Hernaiz-Algarra, M. Arauzo-Sánchez, and I. Carrasco-Martín. 2008. Effect of a nitrification inhibitor (DMPP) on nitrate leaching and maize yield during two growing seasons. Spanish Journal of Agricultural Research 6:294-303.

Fernández-Escobar, R., M. Benlloch, E. Herrera, and J.M. GarcíaNovelo. 2004. Effect of traditional and slow-release $\mathrm{N}$ fertilizers on growth of olive nursery plants and $\mathrm{N}$ losses by leaching. Scientia Horticulturae 101:39-49.

Flórez, V., A. Fernández, D. Miranda, B. Chaves, and J. Guzmán. 2006. Avances sobre fertirriego en la floricultura colombiana. 502 p. Editorial Universidad Nacional de Colombia, Unibiblos, Bogotá, Colombia.

Gonzalez-Real, M.M., and A. Baille. 2000. Changes in leaf photosynthesis parameter with leaf position and nitrogen content within a rose plant canopy (Rosa hybrida). Plant Cell Environment 23:351-363

Good, A.G., A.K. Shrawat, and D.G. Muench. 2004. Can less yield more? Is reducing nutrient input into the environment compatible with maintaining crop production? Trends in Plant Sciences 9:597-605.

Hak, R., U. Rinderle-Zimmer, H.K. Lichtenthaler, and L. Natr. 1993. Chlorophyll a fluorescence signatures of nitrogen deficient barley leaves. Photosynthetica 28:151-159.

Henao, M., and V. Flórez. 2006. Relación entre la composición química de los lixiviados y el tipo de sustrato en un sistema de producción de rosa en clavel sin suelo. p. 265-282. In V. Flórez et al. (eds.) Avances sobre fertirriego sobre la floricultura colombiana. Universidad Nacional de Colombia, Unibiblos, Bogotá, Colombia.

Hunt, E.R., J.A. Weber, and D.M. Gates. 1985. Effects of nitrate application on Amaranthus powellii Wats. III. Optimal allocation of leaf nitrogen for photosynthesis and stomatal conductance. Plant Physiology 79:619-624.

Irigoyen, I., C. Lamsfus, P. Aparicio-Tejo, and J. Muro. 2006. The influence of 3,4-dimethylpyrazole phosphate and dicyandiamide on reducing nitrate accumulation in spinach under Mediterranean conditions. Journal Agricultural Science 144:555-562.
Jull, L.G., S.L. Warren, and F.A. Blazich. 1994. Nitrogen nutrition of containerized Cryptomeria japonica 'Elegans Aurea'. Journal of Environmental Horticulture 12:212-215.

Li, H., X. Liang, Y. Chen, Y. Lian, G. Tian, and W. Ni. 2008. Effect of nitrification inhibitor DMPP on nitrogen leaching, nitrifying organisms, and enzyme activities in a rice-oilseed rape cropping system. Journal of Environmental Science 20:149-155.

Maathuis,F. 2009. Physiological functions of mineral macronutrients. Current Opinion in Plant Biology 12:250-258.

Markwell, J., J.C. Osterman, and J.L. Mitchell. 1995. Calibration of the Minolta SPAD-502 leaf chlorophyll meter. Photosynthesis Research 46:467-472.

Marschner, H. 1995. Mineral nutrition of higher plants. Academic Press, London, UK.

Melgar, J.C., A.W. Schumann, and J.P. Syvertsen. 2010. Fertigation frequency affects growth and water and nitrogen use efficiencies of swingle citrumelo citrus rootstock seedlings. HortScience 45:1255-1259.

Monomeros. 2008. Fertilizantes con tecnología ENTEC® para cultivos aún más productivos. Noticias Positivas. Available at http://www.monomeros.com/descargas/d+noticias.pdf (accessed October 2012).

Mulvaney, R. 1996. Nitrogen inorganic forms. p. 1123-1184. In D. Sparks et al. (eds.) Methods of soils analysis. Part 3. Chemical methods. SSSA, Madison, Wisconsin, USA.

Paramasivam, S., and A.K. Alva. 1997. Leaching of nitrogen forms from controlled-release nitrogen fertilizers. Communications in Soil Science and Plant Analysis 28:1663-1674.

Quiñones, A., B. Martínez-Alcántara, U. Chi-Bacab, and F. Legaz. 2009. Improvement of $\mathrm{N}$ fertilization by using the nitrification inhibitor DMPP in drip-irrigated citrus trees. Spanish Journal of Agricultural Research 7:190-199.

Rodrigues, M.A. 2004. An in situ incubation technique to measure the contribution of organic nitrogen to potatoes. Agronomie 24:249-256.

Rodrigues, M.A., H. Santos, S. Ruivo, and M. Arrobas. 2010. Slowrelease $\mathrm{N}$ fertilisers are not an alternative to urea for fertilisation of autumn-grown tall cabbage. European Journal of Agronomy $32: 137-143$.

Serna, M., J. Banuls, A. Quinones, E. Primo-Millo, and F. Legaz. 2000. Evaluation of 3,4-dimethylpyrazole phosphate as a nitrification inhibitor in a citrus-cultivated soil. Biology and Fertility of Soils 32:41-46.

Taras, M. 1967. Standard methods for the examination of water and wastewater including bottom sediments and sludges. American Public Health Association, New York, USA.

US Department of Health, Education, Welfare. 1962. Public Health Service drinking water standards. Public Health Service Publication nr 956. 76 p. US Department of Health, Education, Welfare, Washington, D.C., USA.

Villalobos, F.J., I. Mateos, F. Orgaz, and E. Fereres. 2002. Fitotecnia: Bases y tecnologías de la producción agrícola. 496 p. Ediciones Mundiprensa, Madrid, España.

Villar, J.M., and E. Guillaumes. 2010. Use of nitrification inhibitor DMPP to improve nitrogen recovery in irrigated wheat on a calcareous soil. Spanish Journal of Agricultural Research 8:12181230.

Zerulla, W., T. Barth, J. Dressel, K. Erhardt, K.H. von Locquenghien, G. Pasda, et al. 2001. 3,4-Dimethylpyrazole phosphate (DMPP) a new nitrification inhibitor for agriculture and horticulture - An introduction. Biology and Fertility of Soils 34:79-84. 